\title{
Hydro chemistry and Characteristics of Groundwater: Case Study Water Contamination at Citarum River Upstream
}

\author{
Mohamad Sapari Dwi Hadian; T. Yan Waliyana'; Nana Sulaksana, Dewandra Bagus Eka \\ Putra ${ }^{2}$, Yuniarti Yuskar ${ }^{2}$ \\ ${ }^{1}$ Faculty of Geology, Universitas Padjadjaran, Jatinangor, Indonesia \\ ${ }^{2}$ Department of Geological Engineering, Universitas Islam Riau, Jl. Kaharuddin Nasution, Pekanbaru 28284, Riau, Indonesia
}

* Corresponding author : sapari@unpad.ac.id

Tel.: +6281321102268

Received: Aug 11, 2017. Revised : Sept 1, 2017, Accepted: Nov 30, 2017, Published: 1 Dec 2017

DOI : 10.24273/jgeet.2017.2.4.578

\begin{abstract}
Rancaekek and Sayang, West Java, are the area where many industrial factories are located. Thus, the region becomes the targeted destination for industrial development. The population in the area is rising due to the growth of industries causing the regional development becomes uncontrollable. In addition, the constant increment of waste and also poor-coordinated disposal systems may result in groundwater contamination in the areas. The rapid growth of the area increases the need for groundwater as well as the need for more research about contamination at Rancaekek and Sayang. The research aims to explore the spread of groundwater contamination in the area. The research method is carried out based on the analysis of Geological Mapping, Hydrogeological Mapping and chemical characteristics of the groundwater in the area. Chemical analyses of the groundwater were conducted through laboratory test of groundwater samples at specific spots of dug wells. The lab test results were further analyzed to determine the contamination zone. The findings reveal that the distribution of contamination in the area follow the shallow groundwater flow patterns, the water contamination contains heavy metal and there is degradation of soil fertility. The findings suggest the stakeholders delineate the contaminated area, and increase the dissemination of environmental awareness.
\end{abstract}

Keywords: Contamination, Groundwater, Hydrogeology

\section{Background}

Water has an important role for human survival. Water is one of the basic needs for the development of human welfare. Therefore, the need for water is a vital requirement to accessible and available for the community. Rancaekek and Sayang, West Java, have been a central area of industrial development. This makes the population in the area has been increasing and growing from year to year. Accordingly, the need for water for daily need as well as for industrial purposes have been increasing rapidly. Depression of groundwater level is considered to be related to the natural shape of the aquifer as lenses. However, it was possible to be caused by overpumping in this zone. (Hadian et al., 2006, 2014, 2016)

In addition, in line with the rapid industrial development in the area, the amount of waste is also increasing. Thus, it has influenced the potential and quality of the groundwater in the area. Therefore, research on groundwater quality in the area, especially regarding groundwater contamination is indispensable (Hem, 1991; Azy \& Hadian, 2016).

\section{Research Method}

To determine the level of contamination of groundwater, this research collected several data such as lithology, groundwater chemical, and land use in the area. The lithologic data was retrieved by geological mapping. The groundwater chemical data was obtained from laboratory test of the groundwater samples taken from certain observation spots. Specific chemical parameters in this study are $\mathrm{Ca} 2+, \mathrm{Mg} \mathrm{2+,} \mathrm{Na}+$ and $\mathrm{K}+, \mathrm{HCO} 3-$, NO32-, SO42- and Cl- (Kumaresan \& Riyazuddin P., 2006). The land use data was taken from literature research. The analysis used in this study was the spatial approach based on certain parameters and presented in the form of thematic maps. The results of this study are expected to be used for hydrogeological studies specifically to indicate the level of groundwater contamination in the area (Hadian et al., 2014; Prayogi, 2015).

\section{Result and Discussion}

\subsection{Geological Mapping of Rancaekek and Sayang}

The area is composed of lithology derived from the volcanic eruption and lacustrine which age has 
reached the quarter. The area is composed of three lithologies: volcanic breccia unit (Qbv), andesitic lava units (Qa) and tuffaceous clay units (QI). The breccias unit is composed by breccias characterized by a light-coloured blackish grey, weathered brownish black, monomic, components of igneous rock in the size of pebble-lump with angled shape and matrix tuf with gray light beige and weathered beige brown colour, open pack, well permeability, medium sorting, and compact. These units are scattered in the north, northeast and southeast areas of the studied area. Andesitic lava is composed by andesite characterized by a light-coloured bluish grey, weathered grey-black, porphyritic, the degree of crystallization hypocrystalline, subhedral crystalline form, compact, mineral quartz content, pyroxene and feldspar. These units are spread in the northern part of the studied area. Tuff clay unit is composed of clay loam tuff characterized by weathered blackish brown colour, ground lustre, soft. These units are spread out in the area dominating from the middle through the southern area (Silitonga, 1973; Soetrisno, 1983). Based on the geological data above (Fig. 1), the findings could not reveal any geological factors that caused the groundwater contamination in the area. (Hadian et al., 2014, 2015; Satrio, 2015, 2017; Barkah, 2015).

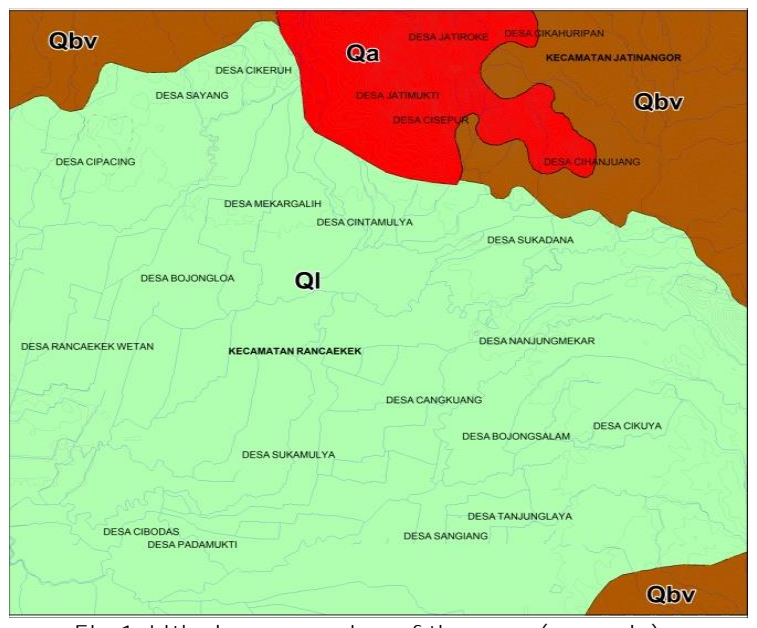

Fig 1. Lithology mapping of the area (no scale)

\subsection{Soil Flow Pattern}

Observations and acquisitions discharge from the position of the wells and springs as well as the depth of the groundwater table elevation contours can describe the unconfined groundwater table or isofreatic in the area (Fig. 2).

The isofreatic map above shows that, in general, under normal conditions, the pattern of the groundwater flow tends to flow along the slope. However, there are conical pattern of the groundwater flow in some places caused by excessive groundwater retrieval exceeding the normal limit, which causes the groundwater level drops drastically and makes the land flow pattern becomes irregular. The condition is more common in the area around Rancaekek.

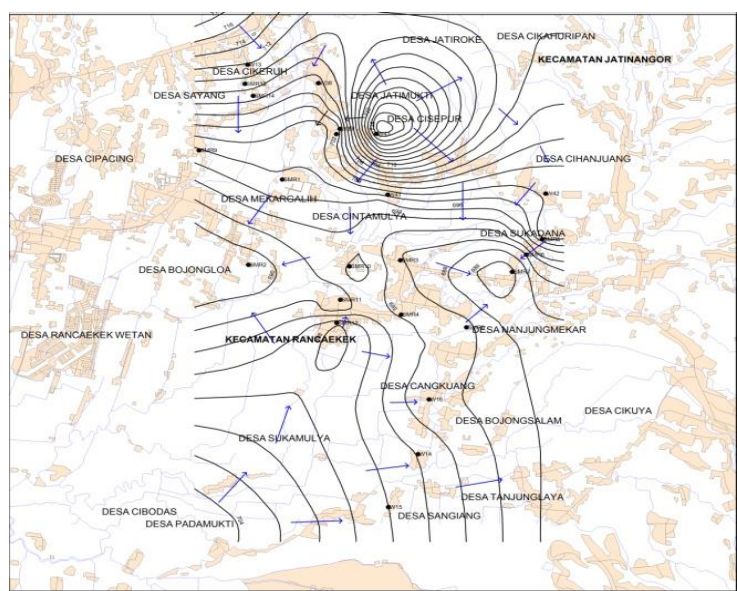

Fig 2. Rancaekek Isofreatic Mapping (no scale)

\subsection{Groundwater Chemical of The Area}

Facies grouping of the groundwater in the areais based on the result of piper diagram analysis using converted water chemical laboratory data.

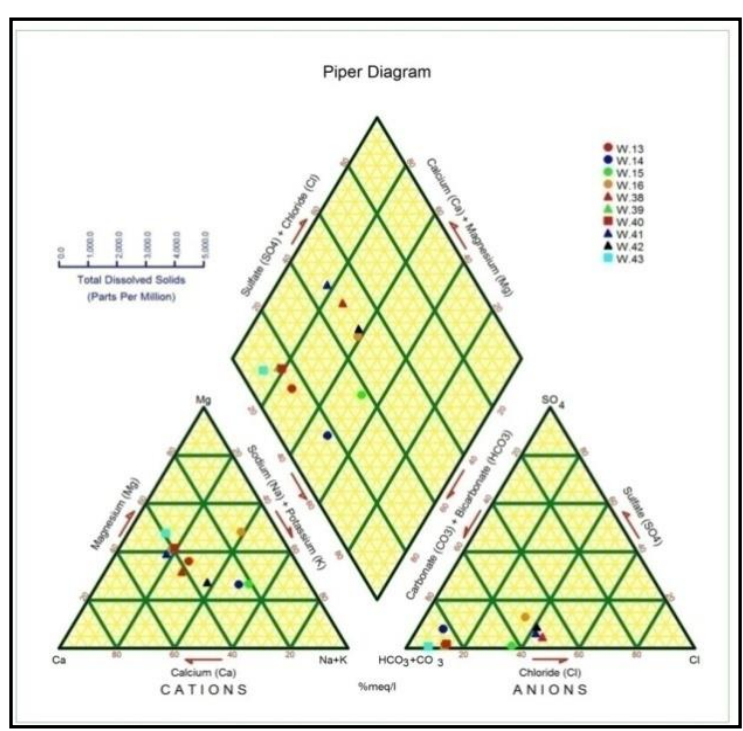

Fig 3. Piper diagram of the groundwater facies in Rancaekek

Based on the analysis using the piper diagram above (Fig. 3), the chemical facies in the area can be grouped into 3 (three) facies, namely facies $\mathrm{Ca}, \mathrm{Mg}$ HCO3 (Calcium, magnesium bicarbonate), facies $\mathrm{Mg}, \mathrm{Na} \mathrm{HCO} 3$ (Magnesium, sodium bicarbonate) , facies $\mathrm{Na}$, Mg HCO3 (sodium, magnesium bicarbonate) (Hadian, 2014).

The trilinear diagram is used to identify the groundwater contamination based on water chemicals in the area. The diagram is used to find out the grouping, similarities or trends of the water sample by measuring the chemical elements of the water from a major element in the area so as to identify anomalies that do not follow the patterns of the trends of each element in each cross-section of the TDI (total dissolved ions) where the anomaly itself is further used as an indication of groundwater contamination (Fig. 4-9). 


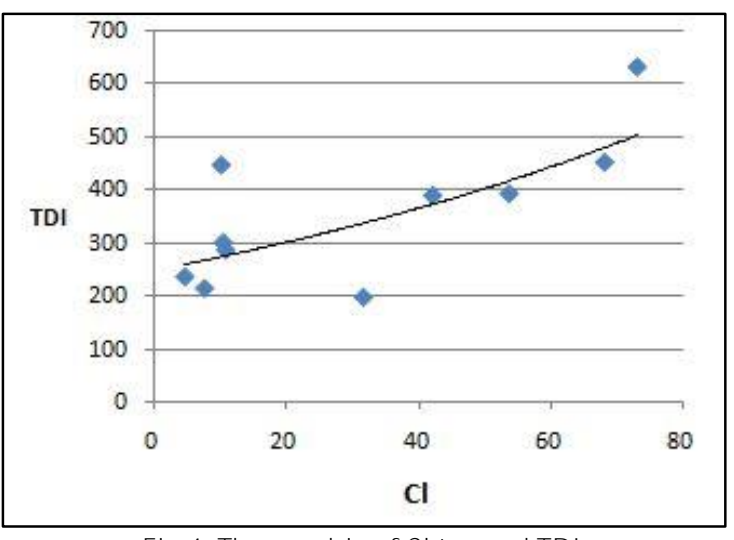

Fig 4. The graphic of $\mathrm{Cl}$ toward TDI

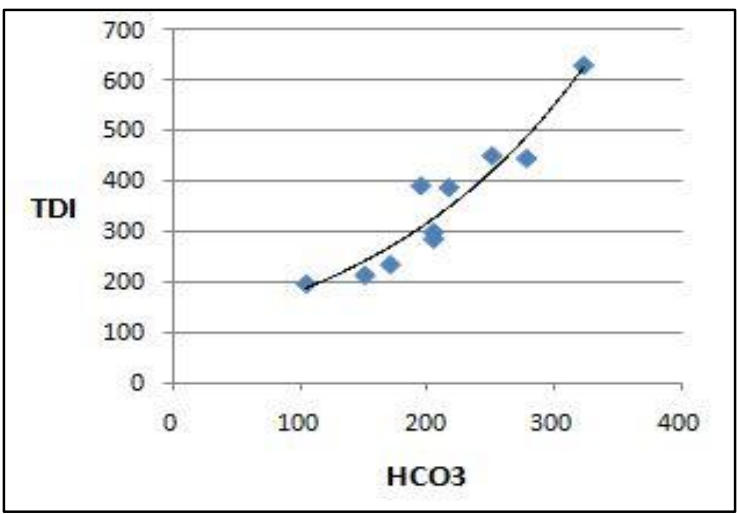

Fig 5. The graphic of $\mathrm{HCO}_{3}$ toward TDI

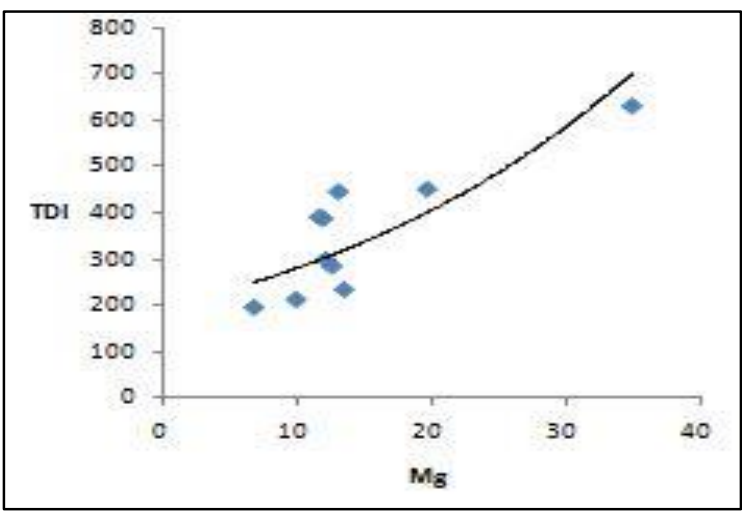

Fig 6. The graphic of $\mathrm{Mg}$ toward TDI

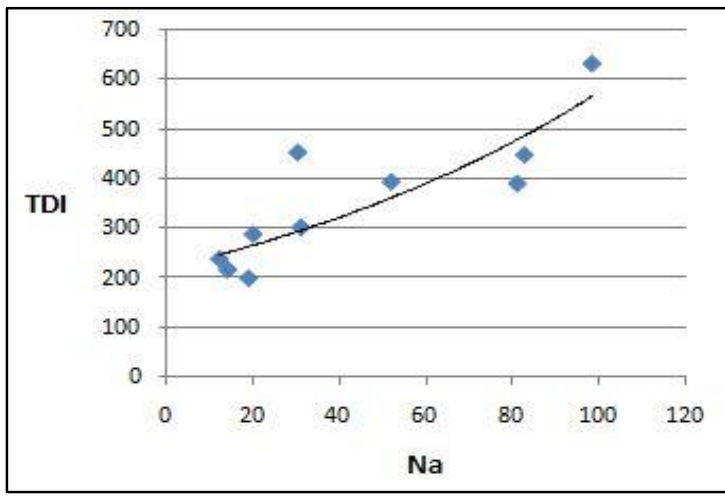

Fig 7. The graphic of Na toward TDI

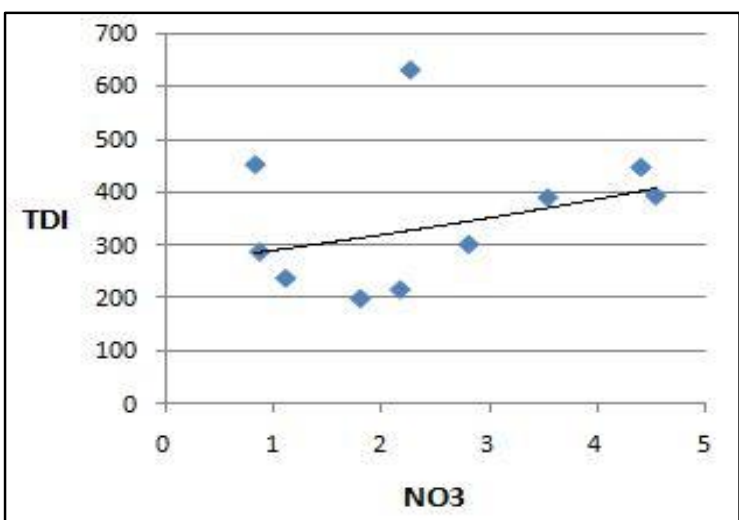

Fig 8. The graphic of $\mathrm{NO}_{3}$ toward TDI

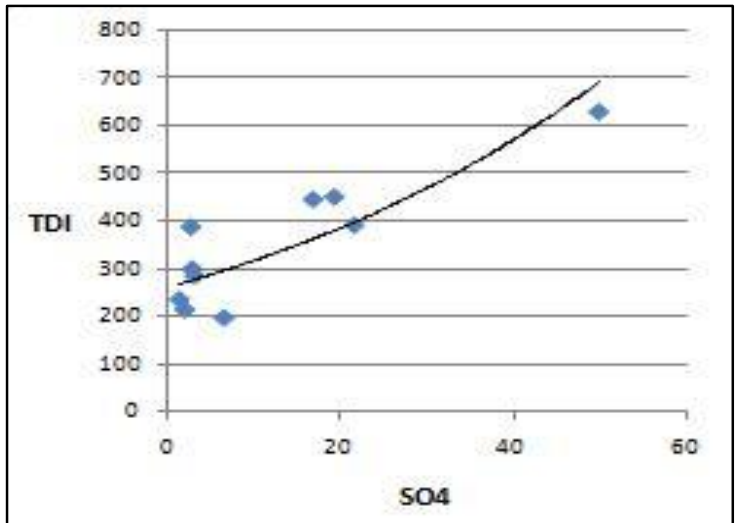

Fig 9. The graphic of $\mathrm{SO}_{4}$ toward TDI

From the data analysis, there are six spots of observation that have been contaminated: station W14, W15, W16, W38, W39 and W41. Those findings were identified based on the anomalies that occur in the diagram $\mathrm{Mg} \mathrm{2+} \mathrm{Na}+$, NO32-, SO42- and Cl-.

According to the analysis of these anomalies as well as the analysis of the land use planning of the area, the groundwater contamination in the area of research was caused by public waste. This is evident from the fact that the spots of contamination are located around the settlement. The groundwater contamination was caused by household waste such as soapy water found from anomalies in the elements $\mathrm{Na}+$, waste fertilizer pat found from anomalies in NO32-, and industrial waste found from anomalies in $\mathrm{Mg} \mathrm{2+}$, SO42 - and Cl.

\section{Conclusion}

Geological conditions in the study area showed the absence of geological factors that cause groundwater contamination. Instead, based on chemical analysis of groundwater, there are indications of groundwater contamination from waste society such as household waste, fertilizers waste and industrial waste. Therefore, groundwater quality management in the area is required so that the potential of the groundwater can be improved to meet the needs of the surrounding people for their life and welfare. 


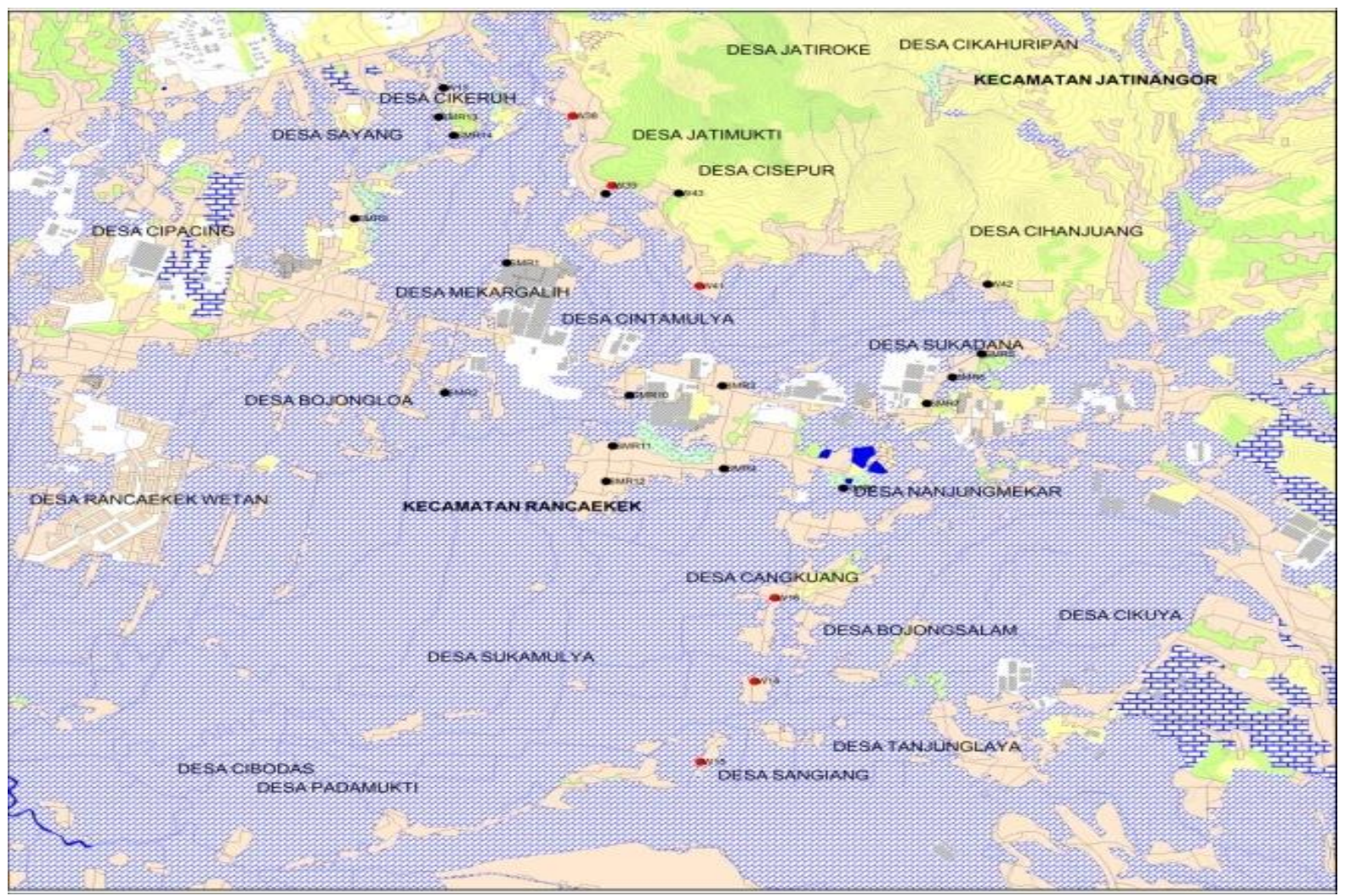

Fig 10. Contaminated spots overlay using land use map

\section{Acknowledgement}

Gratitude is given to the researchers: Dr. Bombom, Prof. Dr. Hendarmawan, Moch. Nursiyam Barkah ST., MT, Environmental Geology and Hydrogeology Laboratory Padjadjaran University for their support and suggestions toward the research and the writing of this article.

\section{References}

Azy, F. N., \& Hadian, M. S. D., 2016. Groundwater Characterization of Cihaur Watershed Basin, Batujajar and Adjacent, West Bandung District, West Java, Indonesia. IOP Conference Series: Earth and Environmental Science 29 (1), p. 012027. IOP Publishing

Barkah, M. N., Setiadi, D. J., Hadian, M. S. D., 2015. Perhitungan Potensi Air Tanah Di Kawasan Kampus Unpad Jatinangor Dengan Metode Numerik. Bulletin of Scientific Contribution 13(3).

Rifai, A., Hadian, S. D., Mufti, I. J., Fathoni, A. R., Azy, F. N., Jihadi, L. H., 2017. Analysis of potential flooding in the education Jatinangor based approach morphology, land cover, and geology. AIP Conference Proceedings 1857 (1), p. 100008. AIP Publishing

Hadian, M. S. D., Azzy, F. N., \& Sophian, R. I., 2016 Geohazard and geological condition overview of Sekeloa-Bojongkoneng, Bandung, West JavaIndonesia. AIP Conference Proceedings 1730 (1), p. 040001. AlP Publishing.

Hadian, M S D., 2014. The Role Of Volcanic Facies Ground Water System Based On Water chemical and Stable Isotopes, Dissertation at Postgraduate Geology Universitas Padjadjaran.

Hadian, M. S., Mardiana, U., Abdurahman, O., Iman, M. I., 2006. Sebaran akuifer dan pola aliran air tanah di Kecamatan Batuceper dan Kecamatan Benda Kota
Tangerang, Propinsi Banten. Indonesian Journal on Geoscience 1(3), 115-128, http://dx.doi.org/10.17014/ijog.vol1no3.20061

Hadian, M. S. D., Yuliwati, A. K., Pribadi, K. N., 2016. Increasing Community Environmental Awareness through Geodiversity Conservation Activities at Ciletuh, Sukabumi, West Java. Journal of Environmental Management \& Tourism 7(2 (14)), 334

Hadian, S. D., Rahmat, B., 2015. Manajemen Airtanah Pada Endapan Aluvium Rawa Lakbok, Jawa Barat. Bulletin of Scientific Contribution 13(3).

Hadian dkk., 2013. Penentuan Zona Resapan Dan Umur Air Pada Endapan Vulkanik Di Kawasan Jatinangor Dengan Mengunakan Metoda Isotop Stabil. Buletin geologi Tata Lingkungan 23(3). ISSN 1410-1696.

Hem, J.D., 1991. Study and Interpretation of chemical characteristics of natural waters U.S. Geol. Surv. Water Supply Paper 2254.

Kumaresan M., Riyazuddin P., 2006. Major ion chemical of environmental samples around suburban of Chennai city. Current Sci., 91(12), 1668 - 1677.

Prayogi, Tantowi E. 2014. Fasies Air Tanah Gunung Geulis Daerah Cisempur dan Sekitarnya, Kecamatan Jatinangor - Rancaekek, Kabupaten Sumedang Bandung Propinsi Jawa Barat. Skripsi pada FakultasTeknik Geologi Universitas Padjadjaran.

Satrio, Prasetio, R., Hadian, M. S. D., Syafri, I., 2017. Stable Isotopes and Hydrochemistry Approach for Determining the Salinization Pattern of Shallow Groundwater in Alluvium Deposit Semarang, Central Java. INDONESIAN JOURNAL OF GEOSCIENCE, 4(1), 1-10

Silitonga, P.H., 1973. Peta gelogi regional lembar Bandung.

Soetrisno, S., 1983. Peta hidrogelogi regional lembar Bandung. 